
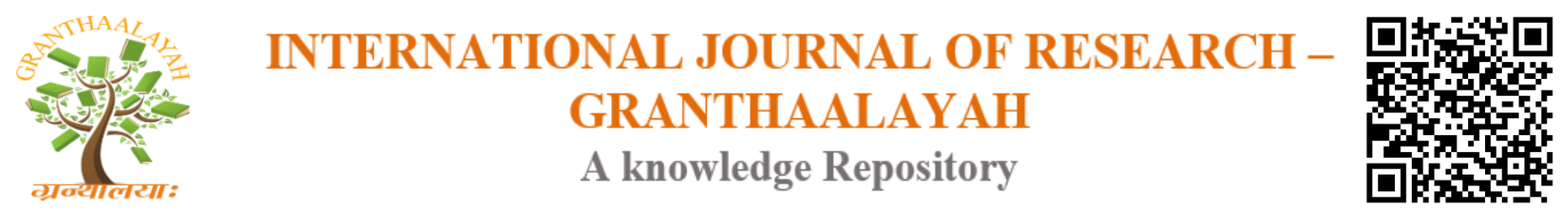

Social

\title{
CONSTRUCTION OF A LIWI'S SCALE ON PERFECTIONISM OF EARLY ADOLESCENTS
}

\author{
A. Linsey Cranab ${ }^{* 1}$, Dr B. William Dharma Raja ${ }^{2}$ \\ ${ }^{* 1}$ UGC-Senior Research Fellow, Department of Education, Manonmaniam Sundaranar \\ University, Tirunelveli- 627 012, India \\ *2 Professor and Head, Department of Education, Manonmaniam Sundaranar University, \\ Tirunelveli- 627 012, India
}

\begin{abstract}
Perfectionism is having both negative and positive aspects. Perfectionism extracts a great toll from early adolescents who think that only through perfection they will be able to gain the fulfilment, success, love, and acceptance of others. Usually, the opposite occurs. Perfectionists may accomplish something but, invariably, their methods will deny them the precise love and acceptance they badly wish to acquire, which leaves them feeling dissatisfied. This article reports on the construction and validation of LiWi's Scale on Perfectionism of early adolescents through a survey from 90 early adolescents. The Cronbach's $\alpha$-value for the selected 32 items were found as 0.790 and this value reflects a good degree of reliability. This scale helps to measure the perfectionist behaviour of an individual and to develop positive perfectionist behaviour among them.
\end{abstract}

Keywords: Perfectionism; Self-Oriented; Others' Oriented; Socially Prescribed Reliability; Early Adolescents.

Cite This Article: A. Linsey Cranab, and Dr B. William Dharma Raja. (2017). "CONSTRUCTION OF A LIWI'S SCALE ON PERFECTIONISM OF EARLY ADOLESCENTS." International Journal of Research - Granthaalayah, 5(12), 106-111. https://doi.org/10.29121/granthaalayah.v5.i12.2017.478.

\section{Perfectionism}

Perfectionism is an underlying reason for the belief that mistakes are never acceptable by the society and only the highest standards of performance is always appreciated by the society. Perfectionists have completely different standards, behaviour, and beliefs. Perfectionism is also associated with cognitive distortion which exhibit unreality. According to Hamachek (1978), 'perfectionism as a manner of thinking about behaviour' with two different types normal and neurotic perfectionism which leads to continuum of perfectionist behaviours (Kendrick \& Johnsen, 2005). 


\subsection{Extensive Research Says...}

From the reviewed studies, it is found that perfectionism was studied among early adolescents, school children, parents, adults, patients, athletes and gifted children. Perfectionism was found to have both negative and positive aspects. Negative perfectionism was most strongly related to higher neuroticism but was also associated with lower extraversion and conscientiousness (Egan, Piek \& Dyck, 2015). There is also an evidence of dysfunctional cognitions and their associations with perfectionistic thinking. Negative perfectionist had higher levels of anxiety, regret and depression and lower level of satisfaction with life; and it has positive relationship with maximization and emotional suppression (Nyland, 2004).

Perfectionism is the key factor of striving for excellence and it could be more in gifted students than non-gifted students (Chan, 2008). Gifted children who seem well- adjusted may suffer from feelings of inadequacy and perfectionistic tendencies (Nugent, 2000). On researching the contribution of parental involvement on perfectionistic tendencies, better the maternal autonomy and maternal Hewitt involvement, self-beliefs will be optimistic which include self-esteem (McArdle, 2008). (Hewitt.,et al, 2000) found that perfectionism contributed to self-harm and suicidal thoughts. Particularly, socially prescribed perfectionism interacted with daily hassles to predict suicidal potential even after controlling for depression, hopelessness, and prior suicide attempt. Socially prescribed perfectionism acts as a vulnerability factor that is predictive of suicide potential or risk among clinically depressed adolescents and adolescent school children (O’Connor, Rasmussen \& Hawton, 2010; Hewitt, Caelian, Chen,\& Flett, 2014).

The self-oriented perfectionism was significantly associated with depression and anxiety, whereas socially prescribed perfectionism was significantly correlated with depression, anxiety, social stress, anger-suppression, and outwardly directed anger (Hewitt et al., 2002). Perfectionism is also categorized into adaptive and maladaptive. Maladaptive perfectionism was positively correlated with suicidal ideation (Kaur \& Rani, 2012). Perfectionistic behaviour was also clinically proven the pertinence of different dimensions of perfectionism to body dissatisfaction. A lower desired BMI (Body Mass Index) was associated with higher levels of concern over mistakes and organisation, and a smaller ideal silhouette was associated with higher levels of concern over mistakes and doubt about actions and organization (Wade\& Tiggemann, 2013). From this it is understood that these flavours of perfectionism have various effects on one's personal and interpersonal life.

\section{Various Types of Perfectionism Scale}

Although there are some perfectionism scales which measure the various characteristics of perfectionism, three of the scales were popular and useful in clinical practice (Egan, Wade, Shafran \& Antony, 2014). They are Frost Multidimensional Perfectionism Scale, 1990; Hewitt and Flett Multidimensional Perfectionism Scale, 1991; Almost Perfect Scale -Revised, 2001 by Slanley, Rice, Mobley, Trippi \& Ashby. Even though these scales are measuring for perfectionism, the items are not apposite for the Indian culture and context. So there is a need of scale on perfectionism for the Indian studies. 


\section{Generation of Items Pool}

Authors reviewed the literature intensively and framed the items pool for perfectionism. When reviewing the literature, it was found that the perfectionism was considered as one of the cognitive distortions (Hewitt \& Flett, 1990). The tool was framed with three dimensions namely self-oriented perfectionism, others' oriented perfectionism and socially prescribed perfectionism. The dimension 'self-oriented perfectionism' helps to find the level of perfectionist behaviour to attain unrealistic and impossible standards.

The dimension 'others ' oriented perfectionism' intends to find the level of demanding perfection from others and also tries to fulfil the expectations of others with high standards. The dimension 'socially prescribed perfectionism' describes the feeling of fear of rejection by the society and how an early adolescent react to that situation.

\section{Construction of LiWi's Perfectionism Scale (LPS)}

To analyse the perfectionism scale, a pool of 55 items were administered to sample of 90 students from six schools in Tirunelveli district, Tamil Nadu, India. The responses were scored as 4, 3, 2, 1 and 0 for positive items and vice versa for negative items. The reliability was found using Cronbach's $\alpha$-value. The Cronbach's $\alpha$-value for 55 items is 0.766. Items with low item total correlation value were dropped and thus 23 items were deleted. The Cronbach's $\alpha$-value for the remaining 32 items were found as 0.790 and this value reflects a good degree of reliability (Field, 2009).

The reliability of LPS was established using test-retest method and the correlation (r) value of it was found to be 0.687 . The tool was given to two experts in the field of psychology and one expert in teacher education for content validity. Based on the suggestions and comments given by the experts, the items were modified. Table 2 shows the Cronbach's $\alpha$-value for the remaining 32 items were found as 0.790 and this value reflects a good degree of reliability (Field, 2009).

\subsection{Final version of LSP}

After item analysis, the valid 32 items were selected for data collection and it was named as LiWi's Scale on Perfectionism (LSP). The following table gives the dimension-wise distribution of items in the final version of LSP.

Table 1: Dimension-wise Distribution of Items in LSP

\begin{tabular}{cc}
\hline Dimension & Item Nos. \\
\hline Self-oriented & $1-14$ \\
Other oriented & $15-28$ \\
Socially prescribed & $29-32$ \\
\hline
\end{tabular}


Table 2: Reliability Statistics for LiWi's Scale on Perfectionism

\section{Cronbach's alpha No. of items}

\begin{tabular}{ll}
\hline 0.790 & 32 \\
\hline
\end{tabular}

\begin{tabular}{|c|c|c|c|c|}
\hline $\begin{array}{l}\text { Item } \\
\text { No. }\end{array}$ & $\begin{array}{l}\text { Scale mean if } \\
\text { item deleted }\end{array}$ & $\begin{array}{l}\text { Scale variance } \\
\text { if item deleted }\end{array}$ & $\begin{array}{l}\text { Corrected item- } \\
\text { total correlation }\end{array}$ & $\begin{array}{l}\text { Cronbach's alpha } \\
\text { if item deleted }\end{array}$ \\
\hline 3 & 82.11 & 246.702 & 0.343 & 0.783 \\
\hline 4 & 82.56 & 233.496 & 0.511 & 0.774 \\
\hline 5 & 83.10 & 239.216 & 0.388 & 0.780 \\
\hline 6 & 82.03 & 243.247 & 0.335 & 0.783 \\
\hline 7 & 82.54 & 244.822 & 0.268 & 0.786 \\
\hline 10 & 83.27 & 244.965 & 0.265 & 0.786 \\
\hline 11 & 84.30 & 243.655 & 0.294 & 0.784 \\
\hline 12 & 81.91 & 244.097 & 0.378 & 0.782 \\
\hline 14 & 83.82 & 245.983 & 0.264 & 0.787 \\
\hline 15 & 81.91 & 248.458 & 0.304 & 0.785 \\
\hline 16 & 82.62 & 237.967 & 0.394 & 0.780 \\
\hline 17 & 81.81 & 245.777 & 0.381 & 0.782 \\
\hline 20 & 83.36 & 245.405 & 0.267 & 0.787 \\
\hline 22 & 82.40 & 247.596 & 0.270 & 0.789 \\
\hline 23 & 81.96 & 243.269 & 0.312 & 0.784 \\
\hline 26 & 82.31 & 246.319 & 0.263 & 0.787 \\
\hline 30 & 83.16 & 244.304 & 0.270 & 0.789 \\
\hline 32 & 82.13 & 245.134 & 0.265 & 0.786 \\
\hline 33 & 81.79 & 245.896 & 0.331 & 0.783 \\
\hline 34 & 82.04 & 245.005 & 0.310 & 0.784 \\
\hline 35 & 81.99 & 248.459 & 0.268 & 0.787 \\
\hline 36 & 81.84 & 244.193 & 0.357 & 0.782 \\
\hline 38 & 83.04 & 243.727 & 0.263 & 0.787 \\
\hline 39 & 83.07 & 241.017 & 0.310 & 0.784 \\
\hline 42 & 82.54 & 246.747 & 0.296 & 0.785 \\
\hline 44 & 81.86 & 248.769 & 0.260 & 0.786 \\
\hline 45 & 83.23 & 244.239 & 0.273 & 0.788 \\
\hline 47 & 83.07 & 241.964 & 0.294 & 0.784 \\
\hline 48 & 82.65 & 243.914 & 0.323 & 0.783 \\
\hline 51 & 82.48 & 244.727 & 0.271 & 0.782 \\
\hline 52 & 82.09 & 246.969 & 0.268 & 0.785 \\
\hline 54 & 81.98 & 245.135 & 0.325 & 0.783 \\
\hline
\end{tabular}

(Item Numbers.1, 2, 8, 9, 13, 18, 19, 21, 24, 25, 27, 28, 29, 31, 37, 40, 41, 43, 46, 49, 50, 53, 55 in the preliminary draft were deleted

\subsection{LiWi's Scale on Perfectionism (LSP)}

Developed by A.Linsey Cranab \& B. William Dharma Raja (2014)

(A - Always, O - Often, S - Sometimes, R - Rarely, N - Never) 


\begin{tabular}{|c|c|c|c|c|c|c|}
\hline S.No. & Statement & $\mathbf{A}$ & $\mathbf{O}$ & $\mathbf{S}$ & $\mathbf{R}$ & $\mathbf{N}$ \\
\hline 1. & I do my works after well planning & & & & & \\
\hline 2. & I am not anxious, when I am late to school. & & & & & \\
\hline 3. & If I make a mistake, I will be upset. & & & & & \\
\hline 4. & I want to be a top rank holder in my class. & & & & & \\
\hline 5. & I feel ashamed to get low marks. & & & & & \\
\hline 6. & $\begin{array}{l}\text { Although I completed my assignments, I doubt whether I have } \\
\text { completed or not. }\end{array}$ & & & & & \\
\hline 7. & I find it hard to relax and enjoy. & & & & & \\
\hline 8. & I am not diligent in completing my assignments. & & & & & \\
\hline 9. & I hesitate to take risks for fear of making mistakes. & & & & & \\
\hline 10. & Whatever I do, I see that it will be in an orderly manner. & & & & & \\
\hline 11. & I prepare a time table of my own and follow it regularly. & & & & & \\
\hline 12. & I strictly follow my school rules and regulations. & & & & & \\
\hline 13. & I get upset if my class hours are altered. & & & & & \\
\hline 14. & $\begin{array}{l}\text { I would like to know everything before and do not like } \\
\text { surprises. }\end{array}$ & & & & & \\
\hline 15. & I like the people who are doing the things in an organized way. & & & & & \\
\hline 16. & When I write, I don't leave space for margin. & & & & & \\
\hline 17. & My parents are expecting beyond my strength. & & & & & \\
\hline 18. & The facilities at my school can be better than what is in now. & & & & & \\
\hline 19. & I like most of my teachers, who are very perfect in their works. & & & & & \\
\hline 20. & I strive very hard to get applause from my teacher. & & & & & \\
\hline 21. & My teachers are expecting high standards from me. & & & & & \\
\hline 22. & $\begin{array}{l}\text { I wish my teachers were excellent in many subjects, so that they } \\
\text { can make it easy for me. }\end{array}$ & & & & & \\
\hline 23. & I prefer to do any task independently. & & & & & \\
\hline 24. & $\begin{array}{l}\text { I feel pride about my work when compared to the work of } \\
\text { others. }\end{array}$ & & & & & \\
\hline 25. & $\begin{array}{l}\text { I will do my work perfectly, because I have the fear of being } \\
\text { rejected and disliked. }\end{array}$ & & & & & \\
\hline 26. & The work without any flaw can only brings good name for me & & & & & \\
\hline 27. & Nobody will care for me, if I failed to achieve something. & & & & & \\
\hline 28. & $\begin{array}{l}\text { I don't feel ashamed, when others notice my grammatical } \\
\text { errors. }\end{array}$ & & & & & \\
\hline 29. & It gives me more stress to appear perfectly in front of others. & & & & & \\
\hline 30. & $\begin{array}{l}\text { I think the society accepts the knowledge that is learnt from } \\
\text { books. }\end{array}$ & & & & & \\
\hline 31. & More excellence is needed to attain the high social status. & & & & & \\
\hline 32. & $\begin{array}{l}\text { Committing to higher goals and working towards it is not } \\
\text { necessary. }\end{array}$ & & & & & \\
\hline
\end{tabular}




\subsection{Usage of Scale on Perfectionism}

The LSP appears to be useful to the early adolescents in scrutinizing whether they have any of these three types of perfectionism. This scale will promote better understanding about selforiented, others' oriented and socially prescribed perfectionism. With this view, educators, parents and early adolescents may analyze the levels of perfectionism. Parents and teachers have to realize that, the process of a task is more important than to be an excellent in a task. Striving for excellence, setting high standards, being order and precise are some of the characteristics of perfectionist people and this LiWi's Scale on Perfectionism helps to identify it.

\section{References}

[1] Egan, S,,Piek, J.,\& Dyck, M. (2015). Positive and negative perfectionism and the big five personality factors. Behaviour Change, 32(2), 104-113.

[2] Egan,S.J., Wade, T. D., Shafran, R., \& Antony,M.T.(2014). Cognitive-Behavioral treatment of perfectionism. New York: Guilford publications.

[3] Field, A. (2009). Discovering statistics using SPSS ( $3^{\text {rd }}$ ed.). London: Sage Publications.

[4] Hewitt et al.,(2002). Perfectionism in children: associations with depression, anxiety, and anger. Personality and Individual Differences, 32(6), 1049-1061.

[5] Hewitt, P.L., \&Flett, G.L. (1990). Perfectionism and depression: A multidimensional analysis. Journal of Social Behavior and Personality, 5, 423-438.

[6] Hewitt, P.L., Caelian, C.F., Chen, C. et al. (2014). Perfectionism, stress, daily hassles, hopelessness, and suicide potential in depressed psychiatric adolescents. Journal of Psychopathology and Behaviour Assessment, 36(4), 663-674.

[7] Kaur., \& Rani. (2012). Suicidal ideation, self-esteem and perfectionism: The victorious triad. Voice of Research, 1(2), 51-57.

[8] Kendrick, J \&Johnsen, S. K. (2005).Teaching and counseling gifted girls. USA: Prufrock Press.

[9] McArdle, S. (2008).Exploring the development of perfectionistic cognitions and self-beliefs. Journal of Cognition, Therapy and Research, 33, 597-614.

[10] Nugent, S.A. (2000). Perfectionism: Its manifestations and classroom based interventions. Journal of Secondary Gifted Education, 11(4).215-221.

[11] Nyland, J.E. (2004). Dysfunctional cognitions: Associations with perfectionistic thinking utilizing the positive and negative perfectionism construct. McNair Scholars Journal, 8(1), 61-67.

[12] O’Connor. R. C., Rasmussen, S.,\&Hawton, K. (2010). Predicting depression, anxiety and selfharm in adolescents: The role of perfectionism and acute life stress. Journal of Behavioural Research \& Therapy, 48(1), 52-59.

[13] Wade, T. D., \&Tiggemann, M. (2013). The role of perfectionism in body dissatisfaction. Journal of Eating Disorders, 1(2). Retrieved from https://jeatdisord.biomedcentral.com/articles/10.1186/2050-2974-1-2

\footnotetext{
*Corresponding author.

E-mail address: linseyasir@gmail.com/widh07@yahoo.com
} 